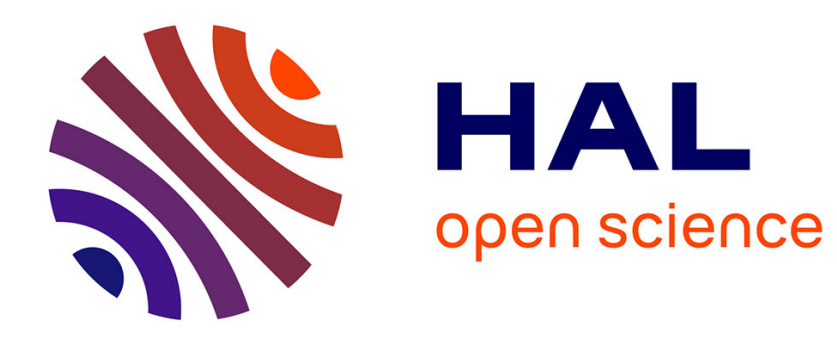

\title{
Climatic shocks and food security: The role of foreign aid
}

\author{
Somlanare Romuald Kinda
}

\section{To cite this version:}

Somlanare Romuald Kinda. Climatic shocks and food security: The role of foreign aid . 2016. hal01260846

\section{HAL Id: hal-01260846 \\ https://hal.science/hal-01260846}

Preprint submitted on 27 Jan 2016

HAL is a multi-disciplinary open access archive for the deposit and dissemination of scientific research documents, whether they are published or not. The documents may come from teaching and research institutions in France or abroad, or from public or private research centers.
L'archive ouverte pluridisciplinaire HAL, est destinée au dépôt et à la diffusion de documents scientifiques de niveau recherche, publiés ou non, émanant des établissements d'enseignement et de recherche français ou étrangers, des laboratoires publics ou privés.

$$
\text { Copyright }
$$




\title{
Climatic shocks and food security: The role of foreign aid
}

\author{
Somlanare Romuald KINDA ${ }^{1}$
}

\begin{abstract}
Little is known about the role that foreign aid can play in dampening the effect of climate change. This paper investigates the role of aid in mitigating the adverse effect of climatic shocks on food security in developing countries. Because foreign aid is an important source of revenue for developing countries, it can enable them to face climatic shocks by mobilizing or stabilizing resources for the financing of agriculture production or food imports. Our results show that foreign aid dampens the effect of climatic shocks on food security. Moreover, the dampening effect is higher for countries that are vulnerable to food price shocks.
\end{abstract}

Keywords: food prices vulnerability, foreign aid, food security, climatic shocks JEL classification: F35, Q17, Q18, Q54

Acknowledgements: I would like to thank UNU-WIDER for providing an excellent working environment.

\footnotetext{
1 Assistant Professor, Universite Ouaga 2, UFR-SEG 03 BP: 7210 Ouagadougou 03, Burkina Faso; Email: skinda@univ-ouaga2.bf and International Consultant, UNIDO Headquarters Vienna International Centre Wagramerstr. 5 P.O. Box 300. A-1400Vienna Austria ; Email: R.KINDA@unido.org
} 
According to several reports (Christensen et al. 2007), greenhouse gases emissions are related to planet warming, and changes in precipitation. This could negatively affect developing and developed countries. There is increasing evidence that greenhouse gases have already begun to warm the planet (Christensen et al. 2007). This in turn will likely cause changes in precipitation patterns as warming trends continue (Christensen et al. 2007). That could have significant negative impacts in both developed and developing countries. For instance Mitchell and Tanner (2006) conclude that southern Africa will probably be 10-20 per cent drier than the previous 5 decades. Moreover climate change will negatively affect agricultural production and food security.

Several authors have analysed relationship between climate change and food security. Christensen et al. (2007) conclude that food production is highly vulnerable to weather conditions. Haile (2005) and Dilley et al. (2005), and Ringler et al. (2010) confirm that food crises and malnutrition in Africa are related to climate events. In addition, Lee et al. (2012) show that climate variability (such as high temperature and precipitation) raises agricultural production in Asian countries while high drop temperatures are detrimental. Badolo and Kinda (2012) show that the impact of climatic variability on food security in developing countries is worsed in presence of civil conflicts or countries that are vulnerable to food price shocks.

Despite these previous studies, little is known about the role that foreign aid flow can play in dampening the effects of climate change. There are several reasons behind the interest in the effect of foreign aid. One of the main motivations is that foreign aid flows are a major source of revenue for developing countries (particularly least developing countries (LDCs)). They can constitute an important mechanism mitigating the effect of climatic shocks on food security because they allow receiving countries to mobilize or stabilize resources for the financing of agriculture production or food import. In the economic literature, several papers have analysed the importance of aid flows as shock absorbers in developing countries. Most of them focus on the effects of foreign aid on macroeconomic stabilizations and coping with various types of shocks. Collier and Dehn (2001) show that aid flow mitigates the negative effect of commodity prices. Chauvet and Guillaumont (2009) and Guillaumont and Chauvet (2001) find that aid is efficient for countries that face economic vulnerability-external shocks (trade, food prices shocks) and natural disasters. However, a limitation of these studies is that they do not analyse the potential role of foreign aid in mitigating the adverse effects of climatic shocks on food security.

This paper explores the role of aid in the mitigation of the effects of climatic variability in the recipient economies. Using panel data for 71 developing countries over the period 1970-2008, results indicate that foreign aid significantly dampens the effect of climatic shocks on food security. More interestingly, it appears that the marginal effect of aid is high for countries that are more vulnerable to food price shocks.

The plan of the paper is as follows. Section 2 contains a discussion of the literature review on the relationship between climatic shocks, foreign aid, and food security. Section 3 discusses the econometric method, and Section 4 presents empirical results. The last section is devoted to concluding remarks and implications. 


\subsection{Determinants of food security}

\subsubsection{Traditionnal factors}

According to the economic literature, many factors may affect food security in developing countries. Badolo and Kinda (2012) group the main factors of food security into three approaches: production-based approach, market-based approach, and institutional failures.

The production-based approach assumes that food security in developing countries can be explained by a decline of food availability. In the economic literature, food availability decline is the result of population growth and the scarcity of natural resources and food security (Malthus (1798), Ehrlich and Ehrlich (1991), Ophuls and Boyan (1992)).

Contrary to production-based approach, the market-based approach considers that famine is not explained by food supply or availability but due to food access. As a precursor of this approach, Sen (1983a) puts in light the concept of entitlements. He suggests that people have an entitlement to food that depends on personal endowments and exchange conditions. The endowments can be defined as the combination of all resources owned by people (for instance land, equipment, animals, knowledge, skills, revenues of employment). Sen (1983a) shows a shift in exchange conditions and employment can reduce the ability of people to acquire food and be a source of insecurity in developing countries. In addition, several authors analyse the link between economic performance and food insecurity. Wiesmann (2006) and Smith and Haddad (2000) show that national incomes contribute to food security because they: (a) strengthen countries' health environments and services and women's education by rising government budgets, (b) raise the ability of countries to buy food in international markets. In addition, through poverty reduction, Smith and Haddad (2000) suggest that economic growth increases food access and security for households.

Final, institutional failures such the implementation of inappropriate policies, the failure of governments, and civil conflicts can affect food delivery (Keen (1994) and Sen 2000). According to Sen (2000), democracy can help to prevent famines. In democracy, leaders are incited to implement policies to fight against food insecurity. Indeed, by bringing out information, free press can favour the implementation of warning systems and policies for food security. Dreze and Sen (1991) and Smith and Haddad (2000) show that democratic institutions are an important determinant of food security. By encouraging human rights (including right to food) and community participation, Haddad and Oshaug (998) and Haddad and Oshaug 1998 conclude that democracy reduces child malnutrition.

\subsubsection{The importance of climatic shocks}

In addition to traditional factors, climatic variability can impact food security in developing countries through several channels (Badolo and Kinda, 2012) that are agricultural production, households incomes, food prices, economic resources and civil conflicts.

First, climatic variability can impact food security through agricultural production. In short term, rainfall variability and extreme events (such droughts and floods) reduce farm yields and decrease agricultural income, and household, and national food availability. In the longer term, it favours underinvestment, agricultural stagnation and rural poverty in countries depending on rainfed agriculture (Kydd et al. 2004). 
Second, rainfall variability can affect food security through household incomes. By decreasing agriculture production, it negatively impacts household income coming from the agriculture sector. According to some authors (for instance International Labour Organization , 2007), 36 per cent (66 per cent) of the world's (sub-Saharan Africa respectively) working population livelihoods depends on agriculture production. In addition to this sector, climatic variability can impact rural labour markets through incomes reduction and a decrease of demand for goods and services in affected areas. Therefore climatic shocks increase the vulnerability of households to food insecurity. For instance, in Africa, climatic variability increases food insecurity through adverse effects on farm revenues (Nhemachena et al. 2010). Furthermore, climatic shocks can increase food insecurity through negative effect on economic growth. For instance, in developing countries Dell et al. (2008) shows that climatic shocks have severe impact on economic growth through a decrease in total productivity, agricultural yields and investments. This reduce the ability of countries to buy food on international markets, to increase investments in infrastructures, services and technology that support food production and to finance public goods such health and education services.

Third, climatic variability affect food security through food prices. By declining food availability in markets, climatic shocks can increase food prices and reduce food accessibility. Using theoretical models, Ringler et al. (2010) conclude that climatic variability favours higher food prices, and childhood malnutrition in sub-Saharan Africa.

Fourth, climatic variability can be a factor of food insecurity by increasing the risk of civil conflicts. Indeed, over the long term, Buhaug (2008) assume that climate shocks will probably lead to substantial scarcity and variability of renewable resources. This will increase the risk of civil conflicts (Miguel et al. 2004) and favour food insecurity.

\subsection{Foreign aid as a resilience factor to climatic shocks}

This subsection is devoted to the analysis of ways to deal with climatic shocks by investigating the role of foreign aid as a risk coping mechanism.

\subsubsection{The stabilizing effect of aid}

Several arguments may justify the stabilizing effect of aid. First, we may consider that foreign aid has a stabilizing effect on economic growth and resources in countries affected by climatic vulnerability. A characteristic of many developing countries is that they have a disproportionate part of their GDP in climate sensitive sectors such as agriculture. Several authors such as Dell et al. (2008) and Mendelsohn et al. (2006) have shown that climatic shocks have large and negative effects on economic growth in poor countries through reduction in agricultural production and exports (Jones and Olken 2010). Foreign aid can be countercyclical and, in presence of climatic shocks (and then revenue shocks), can reduce public spending volatility.

Second, the economic literature (Chauvet and Guillaumont 2009; Guillaumont and Chauvet 2001) on aid and economic growth has shown that foreign aid is more efficient in vulnerable countries by allowing economic growth to become more stable. By stabilizing the economic resources (potentially affected by climatic shocks), foreign aid contributes to reducing the instability of public investment necessary to finance public services (health, education, infrastructures) that support food and agricultural production.

Third, foreign aid can mitigate the effect of climatic shocks on food availability in the recipient countries through the vulnerability of countries to food price shocks. Indeed, Combes et al. 
(2012) show that foreign aid has a dampening effect on the impact of food price shocks on both level and volatility of household consumption. Moreover climatic variability favours food insecurity through food price shocks vulnerability (Badolo and Kinda 2012). Therefore, the dampening effect of aid may be high for countries that are more vulnerable to food price shocks. Moreover, aid may favour the implementation of economic reforms (Collier 1997; Morrissey 2004) reducing the high level and volatility of food prices in developing countries. Indeed better economic and trade reforms reduce the dispersion of food prices in non-integrated markets (Aker 2010; Araujo et al. 2005).

\subsubsection{Aid and capacity building}

Beyond the importance of more financial resources (foreign aid), developing countries need technical resources to strengthen institutions. Indeed, one problem that faces developing countries is the lack of capacity building to withstand climate change. According to UNDP (2009), capacity is 'the ability of individuals, institutions and societies to perform functions, solve problems, and set and achieve objectives in a sustainable manner'.

By providing education (skills), experience, and knowledge, external technical experts allow many developing countries to implement mitigation and adaptation policies against climate change. According to Nelson and Phelps (1966), education increases people's ability to understand information, and adopt new behaviours. It allows people (agricultural households for example) to adopt new technologies such as drought and heat tolerance crop varieties. Foreign aid may facilitate the implementation of climate change adaptation policies in agricultural science and technology, water conservation, risk management, and capacity building (Huang 2013). Moreover, foreign aid might finance investments that increase the flexibility of the economy. By financing education, individuals can become more adaptable and less dependent on climate sensitive sectors (agriculture for example).

In other words, the capacity building efforts of foreign aid may potentially contribute to reduce the negative effect of climate change by improving the quality of human resources (through education), the transfer of new technologies and good practices from other countries (through international cooperation, networking, and information sharing), and by increasing income.

\section{Empirical analysis}

\subsection{Empirical model}

The aim of the paper is to analyse the role of aid in the mitigation of the effects of climatic shocks on food security. For this purpose, we follow the following steps:

First, we test the effect of climatic shocks on food security. The baseline equation is:

$$
Y_{i, t}=\alpha_{i}+\beta_{1} C S_{i, t}+\omega X_{i, t}+\gamma_{t}+\varepsilon_{i, t}
$$

With $C S_{i, t}$ the variable of climatic variability $(\log )$ in a country $\mathrm{i}$ at the period $\mathrm{t} ; \varepsilon_{i, t}$ is the error term, $\gamma_{t}$ represents time fixed effect, and $\alpha_{i}$ country fixed effects. $X_{i, t}$ is the matrix of control variables. They are population growth, income per capita (log), democratic institutions, arable land $(\log )$, cereal production land $(\log )$ and real effective exchange rate $(\log ) . Y_{i, t}$ is the food 
supply. Because food security is a multidimensional concept, we use the proportion of undernourished people for robustness checks.

Second, we analyse the mitigating effect of Aid. To test this hypothesis, we adopt the following specification (equation 2):

$$
Y_{i, t}=\alpha_{i}+\beta_{1} C S_{i, t}+\beta_{2} C S_{i, t} * \operatorname{Aid}_{i, t}+\beta_{3} \operatorname{Aid}_{i, t}+\omega X_{i, t}+\gamma_{t}+\varepsilon_{i, t}
$$

With Aid $_{i, t}$ the amount of official development assistance (ODA) per capita. If this hypothesis is proven to be true, the coefficient associated to the interactive term $\left(\beta_{2}\right)$ will be positive. The hypotheses tested are : $\beta_{1}<0 \quad \beta_{2}>0$ and $\beta_{3}>=0$

\section{Estimation strategy}

In order to estimate our models (equations (1), (2)), we may apply ordinary least square (OLS), fixed effects (FE) or random effect (RE). However OLS don't take into account unobserved heterogeneity of countries. Therefore it is adequate to apply fixed effects (FE) or random effect (RE). In order to choose the adequate specific effect, we will use the Hausman test.

\subsection{Data sources and description of variables}

Data cover the period from 1960 to 2008 for 71 developing countries and are compiled in fiveyear averages (1960-1964, 1965-1969...). The data on foreign aid, population growth, income per capita, and proportion of undernourished people are from World Bank Statistics (World Bank Group 2011). Those on democratic institutions, rainfall, and food supply are from respectively Polity IV (2011), Cerdi and Food and Agriculture Organization (2011).

\subsubsection{Food security}

According to the United Nations Development Programme (UNDP 1994), food security can be defined as "a situation that exists when all people at all times have physical, social and economic access to sufficient, safe and nutritious food that meets their dietary needs and food preferences for an active and healthy life". In the literature several indicators have be used because food security is a multidimensional and flexible concept. Similarly to Badolo and Kinda (2012), we use two complementary indicators ${ }^{2}$ : proportion of undernourished people and food supply per capita. Food supply per capita is a simple average of food supplies of main cereals consumed in developing countries. There are maize, rice, sorghum, millet, and wheat, soybeans and sugar.

\subsubsection{Rainfall variability}

Climatic variability is measured by the standard deviation of the growth rate of rainfall, which is frequently used in economic literature. It is computed as the five-year rolling standard deviation of the growth rate of rainfall series.

\section{$4 \quad$ Results}

\footnotetext{
${ }^{2}$ bThe global hunger index is currently considered as the best indicator of food security. However it is not available over the long period of time.
} 


\subsection{Baseline results}

Columns 1 and 2 of table 1 show the results of the effects of rainfall variability on food insecurity with fixed effects (FE) and random effects (RE) respectively. The Hausman test shows that the fixed effect model is more appropriate than the random effect model. Therefore we use FE. We find that rainfall variability reduces food supply in developing countries. This result is similar to Badolo and Kinda (2012). According to them, results are explained by several reasons. Climatic variability is a factor of uncertainty and raises fluctuation in agricultural production. climatic variability raises fluctuation in agricultural production and negatively impact household incomes. This effect may be higher for countries that depend on rainfall for agriculture production (rainfed agriculture). In addition, through agriculture production reduction, climatic variability can reduce agricultural incomes and economic growth (Dell et al. 2008) in developing countries. Therefore their ability to import food (from international markets) will be limited.

In next step, we include control variables to check the robustness of results (from column 3 to 5 of table 1). There are cereal production land, arable land and real effective exchange rate. The results conclude that rainfall variability has a negative impact on food supply. Moreover land use improves food supply and production. The real effective exchange rate has no impact on food supply per capita. 
Table 1: Impact of rainfall variability on food supply per capita

\begin{tabular}{|c|c|c|c|c|c|}
\hline Dependent variable & $\begin{array}{l}\text { Food Supply } \\
(1) \\
\text { FE }\end{array}$ & $\begin{array}{l}(2) \\
\mathrm{RE}\end{array}$ & $\begin{array}{l}\text { (3) } \\
\mathrm{FE}\end{array}$ & $\begin{array}{l}(4) \\
\text { FE }\end{array}$ & $\begin{array}{l}(5) \\
\text { FE }\end{array}$ \\
\hline Rainfall variability & $\begin{array}{l}-0.0179 \text { *** } \\
(-2.802)\end{array}$ & $\begin{array}{l}-0.0194^{\star \star *} \\
(-2.986)\end{array}$ & $\begin{array}{l}-0.0167^{* * *} \\
(-2.899)\end{array}$ & $\begin{array}{l}-0.0140 \text { ** } \\
(-2.308)\end{array}$ & $\begin{array}{l}-0.0196 \text { ** } \\
(-1.976)\end{array}$ \\
\hline Rainfall & $\begin{array}{l}0.148^{* \star} \\
(2.036)\end{array}$ & $\begin{array}{l}0.0209^{* *} \\
(2.403)\end{array}$ & $\begin{array}{l}0.122^{* \star} \\
(2.443)\end{array}$ & $\begin{array}{l}0.118^{*} \\
(1.702)\end{array}$ & $\begin{array}{l}0.110 \\
(0.909)\end{array}$ \\
\hline Income per capita & $\begin{array}{l}0.0557^{\star * *} \\
(2.079)\end{array}$ & $\begin{array}{l}0.107^{\star \star \star} \\
(4.533)\end{array}$ & $\begin{array}{l}0.0688^{\star * *} \\
(2.827)\end{array}$ & $\begin{array}{l}0.0785^{\text {}} \\
(3.060)\end{array}$ & $\begin{array}{l}0.0233 \\
(0.579)\end{array}$ \\
\hline Population growth & $\begin{array}{l}-0.0300^{\star \star *} \\
(-2.816)\end{array}$ & $\begin{array}{l}-0.0257^{* *} \\
(-2.414)\end{array}$ & $\begin{array}{l}-0.0165^{\star} \\
(-1.694)\end{array}$ & $\begin{array}{l}-0.0237^{\star *} \\
(-2.339)\end{array}$ & $\begin{array}{l}-0.0547^{\star *} \\
(-2.241)\end{array}$ \\
\hline Democratic institutions & $\begin{array}{l}-0.000663 \\
(-0.185)\end{array}$ & $\begin{array}{l}0.000476 \\
(0.136)\end{array}$ & $\begin{array}{l}-0.00200 \\
(-0.617)\end{array}$ & $\begin{array}{l}-0.000159 \\
-0.0467)\end{array}$ & $\begin{array}{l}0.000497 \\
(0.0940)\end{array}$ \\
\hline Cereal production land & & & $\begin{array}{l}0.259^{* * \star} \\
(9.772)\end{array}$ & & \\
\hline Arable land & & & & $\begin{array}{l}0.269^{* * *} \\
(6.983)\end{array}$ & \\
\hline Exchange rate (REER) & & & & & $\begin{array}{l}-0.0242 \\
(-1.449)\end{array}$ \\
\hline Intercept & $\begin{array}{l}4.238^{* * *} \\
(7.994)\end{array}$ & $\begin{array}{l}4.780^{* * *} \\
(13.81)\end{array}$ & $\begin{array}{l}0.796 \\
(1.335) \\
\end{array}$ & $\begin{array}{l}3.754^{* * *} \\
(7.391)\end{array}$ & $\begin{array}{l}4.826^{\star * \star} \\
(5.606)\end{array}$ \\
\hline Observations & 517 & 517 & 517 & 517 & 517 \\
\hline Countries & 71 & 71 & 71 & 71 & 71 \\
\hline R-squared & 0.289 & & 0.417 & 0.361 & 0.299 \\
\hline
\end{tabular}

Note: $t$-statistics are presented in parentheses under the estimated coefficients. ${ }^{* * *},{ }^{* *}$ and ${ }^{*}$ indicate significance of the estimated coefficient at 1,5 , and 10 per cent, respectively. The study period is 1960-2008.

Source: Author's estimate. 


\subsection{The role of aid}

This section focuses on the importance of foreign aid. We assume that foreign aid can improve food security in developing countries. Moreover, we consider that the negative effect of climatic shocks on food security could be less high in the presence of foreign aid.

Table 2 presents the results of the non-linear impact of climatic shocks on food supply, depending upon the aid. Unsurprisingly, climatic shocks always seem to be associated with food insecurity in developing countries. The results (column 2 of Table 2 ) indicate that the coefficients associated with climatic shocks and to the interactive term (climatic shocks *Aid) are negative and positive respectively. This result reveals that the negative impact of climatic variability on food supply decreases with aid. In other words, climatic shocks are factor of food insecurity in developing countries although its effect is mitigated in the presence of aid. These results confirm the idea that foreign aid acts as climatic shock absorbers in the recipient countries. First, foreign aid can be countercyclical and, in presence of climatic shocks (and then revenue shocks), smooths public spending. Second, by stabilizing economic resources (potentially affected by climatic shocks), foreign aid contributes to reduce the instability of public investment necessary to finance public services (health, education, infrastructure) that support food and agricultural production.

Previous authors (Guillaumont and Chauvet 2001; Chauvet and Guillaumont 2009) have concluded that foreign aid is more effective in vulnerable countries by allowing economic growth to become more stable. Moreover Badolo and Kinda (2012) conclude that the negative impact of climatic shocks are high for vulnerable countries that are less able to maintain food availability. We assume that the role of aid as climatic shock absorber will be high in the most vulnerable countries. In order to test this hypothesis empirically, equation (3) is estimated with the most vulnerable countries in the sample (above the 75th percentile of the distribution of the vulnerability index). Column 3 of table 2 shows that the negative effect of climatic shocks on food security increases when the sample is restricted to the countries above the 75 th percentile of the vulnerability index. For this restricted sample, the aid has a powerful dampening effect on the negative impact of climatic shocks on food security in developing countries (column 4 of Table 2). 
Table 2: Rainfall variability, foreign aid, and food supply per capita

\begin{tabular}{|c|c|c|c|c|}
\hline Dependent variable & \multicolumn{2}{|c|}{$\begin{array}{l}\text { Food Supply per capita } \\
\text { Full sample }\end{array}$} & $\begin{array}{l}\text { Vul>75th per. } \\
\text { (3) }\end{array}$ & $(4)$ \\
\hline Rainfall variability & $\begin{array}{l}-0.0179^{\star \star \star} \\
(-2.802)\end{array}$ & $\begin{array}{l}-0.0718^{* * *} \\
(-2.859)\end{array}$ & $\begin{array}{l}-0.0511^{* *} \\
(-2.573)\end{array}$ & $\begin{array}{l}-0.114^{* * *} \\
(-2.741)\end{array}$ \\
\hline Rainfall variability* & & $0.0430^{*}$ & & $0.0602^{*}$ \\
\hline & & $(1.941)$ & & (1.662) \\
\hline Aid per capita & & $\begin{array}{l}0.000296 \\
(0.797)\end{array}$ & & $\begin{array}{l}0.000976 \\
(1.309)\end{array}$ \\
\hline Rainfall & $\begin{array}{l}0.148^{\star *} \\
(2.036)\end{array}$ & $\begin{array}{l}0.208 \\
(1.567)\end{array}$ & $\begin{array}{l}0.526^{\star *} \\
(2.510)\end{array}$ & $\begin{array}{l}0.561^{\star *} \\
(2.592)\end{array}$ \\
\hline Income per capita & $\begin{array}{l}0.0557^{* *} \\
(2.079)\end{array}$ & $\begin{array}{l}0.205^{\star \star *} \\
(4.577)\end{array}$ & $\begin{array}{l}0.358^{\star \star \star} \\
(5.056)\end{array}$ & $\begin{array}{l}0.352^{\star \star \star} \\
(4.205)\end{array}$ \\
\hline Population growth & $\begin{array}{l}-0.0300^{* * *} \\
(-2.816)\end{array}$ & $\begin{array}{l}-0.00438 \\
(-0.288)\end{array}$ & $\begin{array}{l}-0.000735 \\
(-0.0401)\end{array}$ & $\begin{array}{l}0.000843 \\
(0.0385)\end{array}$ \\
\hline $\begin{array}{l}\text { Democratic } \\
\text { institutions }\end{array}$ & -0.000663 & -0.00175 & -0.00837 & -0.00970 \\
\hline Intercept & $\begin{array}{l}(-0.185) \\
4.238^{\star * *} \\
(7.994)\end{array}$ & $\begin{array}{l}(-0.316) \\
2.844^{* \star *} \\
(2.902)\end{array}$ & $\begin{array}{l}(-0.974) \\
-4.90 e-05 \\
(-3.30 e-05)\end{array}$ & $\begin{array}{l}(-1.102) \\
-0.530 \\
(-0.336)\end{array}$ \\
\hline Observations & 517 & 370 & 215 & 194 \\
\hline R-squared & 0.289 & 0.117 & 0.186 & 0.254 \\
\hline Countries & 71 & 67 & 43 & 38 \\
\hline
\end{tabular}

Note: t-statistics are presented in parentheses under the estimated coefficients. ${ }^{* * *},{ }^{* *}$ and ${ }^{*}$ indicate significance of the estimated coefficient at 1, 5, and 10 per cent, respectively. The study period is 1960-2008.

Source: Author's estimate.

\subsection{Robustness checks}

\subsubsection{Inertia of food supply and dealing with endogeneity of aid}

Is food supply characterized by inertia phenomena? In other words, it is important to know if the lagged level of food supply is a potential determinant of the current level of food supply. We include the lagged level of food supply in our baseline equation. The dynamic nature of our specified model requires the implementation of Generalized Method of Moments (GMM) estimation from Arellano and Bond (1991), Arellano and Bover (1995), and Blundell and Bond (1998).

Because aid aims to improve food security (to reduce poverty) in the receiving country, we may assume that countries with greater needs (food insecurity, macro vulnerability, etc.) will receive more aid. The econometric estimation of model facing reverse causality between aid and food security requires us to deal correctly with endogeneity. We use lagged variables (aid per capita) to control for endogeneity. The results in Table 3 show that the lagged level of food supply has no effect on its current level (columns 2). There is no inertia for food supply in developing countries. In addition, using lagged variables to control for endogeneity of aid does not alter the previous results.

\subsubsection{Complementary indicator of food security}

We consider the proportion of undernourished people as another indicator of food security. In column (1) of table 4, we find that rainfall variability has an effect on the proportion of undernourished people. Column (2) reveals that the impact of climatic variability on malnutrition decreases with aid. Column (3) shows that aid has a powerful dampening effect for countries that are highly vulnerable to food price shocks (above the 75th percentile of the vulnerability index). 
Table 3: Impact of climatic variability on food security: inertia of food supply and endogeneity of aid

\begin{tabular}{lll}
\hline \hline Dependent variable & $\begin{array}{l}\text { Food Supply } \\
\text { Fixed effects }\end{array}$ & $\begin{array}{l}\text { GMM-system } \\
\text { Two step }\end{array}$ \\
\hline Lagged food supply & & 0.0150 \\
& $(0.540)$ \\
Rainfall variability & $-0.0718^{\star * *}$ & $-0.106^{*}$ \\
& $(-2.859)$ & $(-1.743)$ \\
Rainfall variability* Aid per capita & $0.0430^{\star}$ & $0.00212^{\star *}$ \\
& $(1.941)$ & $(2.344)$ \\
Aid per capita & 0.000296 & $0.0334^{\star *}$ \\
& $(0.797)$ & $(2.489)$ \\
Rainfall & 0.208 & -0.106 \\
& $(1.567)$ & $(-1.245)$ \\
Income per capita & $0.205^{\star * *}$ & 0.0723 \\
& $(4.577)$ & $(1.447)$ \\
Population growth & -0.00438 & $-0.119^{* *}$ \\
& $(-0.288)$ & $(-2.191)$ \\
Democratic institutions & -0.00175 & 0.00324 \\
& $(-0.316)$ & $(0.645)$ \\
Intercept & $2.844^{* * *}$ & $1.513^{* * *}$ \\
& $(2.902)$ & $(2.825)$ \\
\hline Observations & 370 & 358 \\
R-squared & 0.117 & 67 \\
Countries & 67 & 0.06 \\
AR(1) & & 0.95 \\
AR(2) & & 0.75 \\
Hansen test & & 24 \\
Instruments & & \\
\hline \hline
\end{tabular}

Note: t-statistics are presented in parentheses under the estimated coefficients. ${ }^{* *},{ }^{* *}$, and * indicate significance of the estimated coefficient at 1, 5, and 10 per cent, respectively. The study period is $1960-2008$.

Source: Author's estimate. 
Table 4: Rainfall variability, foreign aid, and proportion of undernourished people

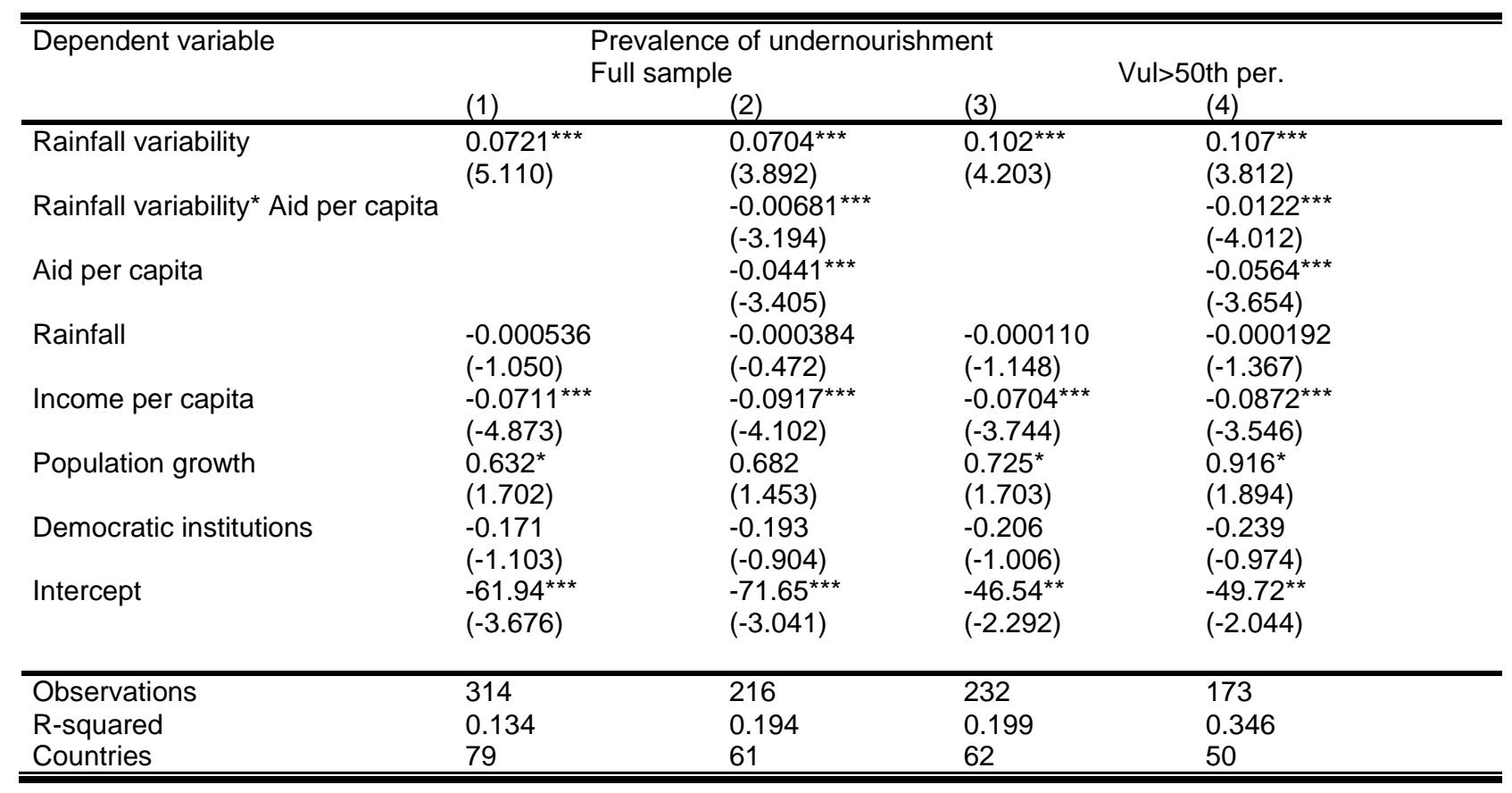

Notes: t-statistics in parentheses; ${ }^{* *} p<0.01,{ }^{* *} p<0.05,{ }^{*} p<0.1$

Source: Author's estimate.

\section{Conclusion}

This paper investigates the role of aid in mitigating the adverse effects of climatic shocks on food security in developing countries. Using panel data for 71 developing countries over the period 1970-2008, our results show that foreign aid significantly dampens the effects of climatic shocks on food security. More interestingly, it appears that the marginal effect of aid is high for countries that are more vulnerable to food price shocks. In other words, when countries exhibit a high level of vulnerability to food price shocks, aid has a strong dampening effect on the impact of climatic shocks on food security.

Our results are important in terms of recommendations for economic policies. While the debate about the role of foreign aid (specially food aid) on food security, is still ongoing, this paper shows that foreign aid dampens the impact of climatic variability on food security. However foreign aid has no direct effect on food supply in developing countries. This result suggests an increase of foreign aid in developing countries. However the policy must be implemented to countries that vulnerable food prices shocks and affected by climatic variability.

\section{References}

Aker, Jenny C. 2010. «Information from Markets Near and Far: Mobile Phones and Agricultural Markets in Niger ». American Economic Journal: Applied Economics 2 (3): 46-59.

Araujo, Claudio, Catherine Araujo Bonjean, Jean-Louis Combes, et Pascale Combes Motel. 2005.

«Devaluation and Cattle Market Integration in Burkina Faso ». Journal of African Economies 14 (3): 359-84.

Arellano, Manuel, et Stephen Bond. 1991. «Some Tests of Specification for Panel Data: Monte Carlo Evidence and an Application to Employment Equations ». Review of Economic Studies 58 (2): 277-97. 
Arellano, Manuel, et Olympia Bover. 1995. «Another look at the instrumental variable estimation of error-components models ». Journal of Econometrics 68 (1): 29- 51.

Badolo, Felix, et Somlanare Romuald Kinda. 2012. «Climatic shocks and food security in developing countries ». MPRA Paper 43006. University Library of Munich, Germany. http://ideas.repec.org/p/pra/mprapa/43006.html.

Badolo, Félix, et Somlanare Romuald KINDA. 2014. «Climatic Variability and Food Security in Developing Countries ». Working Paper halshs-00939247. HAL. http://ideas.repec.org/p/hal/wpaper/halshs-00939247.html.

Blundell, Richard, et Stephen Bond. 1998. «Initial conditions and moment restrictions in dynamic panel data models ». Journal of Econometrics 87 (1): 115- 43.

Buhaug, Halvard. 2008. «Implications of Climate Change for Armed Conflict». The Social Development Department The World Bank Group.

Chauvet, Lisa, et Patrick Guillaumont. 2009. « Aid, Volatility, and Growth Again: When Aid Volatility Matters and When It Does Not». Review of Development Economics 13 (3): 452- 63. doi:10.1111/j.1467-9361.2009.00501.x.

Christensen et al. 2007. «Climate change 2007: The physical science basis ». Agenda 6: 07.

Collier, Paul, et Jan Dehn. 2001. «Aid, shocks, and growth». Policy Research Working Paper Series 2688. The World Bank. http://ideas.repec.org/p/wbk/wbrwps/2688.html.

Combes, Jean-Louis, Christian Ebeke, Mireille Ntsama Etoundi, et Thierry Yogo. 2012. « Are Foreign Aid and Remittances a Hedge against Food Price Shocks in Developing Countries? » Working Paper halshs-00608128. HAL. http://ideas.repec.org/p/hal/wpaper/halshs-00608128.html.

Dell, Melissa, Benjamin F. Jones, et Benjamin A. Olken. 2008a. "Climate Change and Economic Growth: Evidence from the Last Half Century ». National Burean of Economic Research Working Paper Series No. 14132. http://www.nber.org/papers/w14132. . 2008b. « Climate Change and Economic Growth: Evidence from the Last Half Century ». National Bureau of Economic Research Working Paper Series No. 14132. http://www.nber.org/papers/w14132.

Dilley, Margaret Arnold, Uwe Deichmann, Robert S. Chen, et Arthur L; Lerner-Lam. 2005. « Natural Disaster Hotspots: A Global Risk Analysis ». Book Review. World Bank.

Dreze, Jean, et Amartya Sen. 1991. «Hunger and Public Action ». OUP Catalogue. Oxford University Press. http://ideas.repec.org/b/oxp/obooks/9780198283652.html.

Ehrlich, Paul R., et Anne H. Ehrlich. 1991. The Population Explosion. Simon \& Schuster.

Food and Agriculture Organization of the United Nations. 2011. «The FAOSTAT Database ». http://faostat.fao.org/site/609/default.aspx\#ancor.

Guillaumont, P., et L. Chauvet. 2001. « Aid and Performance: A Reassessment ». Journal of Development Studies 37 (6): 66-92. doi:10.1080/713601083.

Haile, Menghestab. 2005. «Weather patterns, food security and humanitarian response in sub-Saharan Africa ». Philosophical Transactions of the Royal Society B: Biological Sciences 360 (1463): 2169 - 82. doi:10.1098/rstb.2005.1746.

International Labor Organization. 2007. «The Decent Work Agenda in Africa ». Report. Geneva: International Labour Organization.

Jones, Benjamin F., et Benjamin A. Olken. 2010. « Climate shocks and exports ». National Bureau of Economic Research. http://www.nber.org/papers/w15711.

Keen David. 1994. The Benefits of Famine: A Political Economy of Famine and Relief in Southwestern Sudan, 19831989. Princeton: Princeton University Press.

Kydd, Jonathan, Andrew Dorward, Jamie Morrison, et Georg Cadisch. 2004. « Agricultural development and pro-poor economic growth in sub-Saharan Africa: potential and policy ». Oxford Development Studies 32 (1): 37- 57.

Lee, Jaehyuk, Denis A. Nadolnyak, et Valentina M. Hartarska. 2012. «Impact of Climate Change on Agricultural Production in Asian Countries: Evidence from Panel Study ». 2012 Annual Meeting, February 4-7, 2012, Birmingham, Alabama 119808. Southern Agricultural Economics Association. http://ideas.repec.org/p/ags/saea12/119808.html.

Malthus, Thomas Robert. 1798. Essai sur le principe de population. Traduit par Pierre Theil. Bibliothèque Médiations. Paris: Editions Gonthier.

http://classiques.uqac.ca/classiques/maltus_thomas_robert/essais_population/essais_populatio n.html. 
Mendelsohn, Robert, Ariel Dinar, et Larry Williams. 2006. «The distributional impact of climate change on rich and poor countries ». Environment and Development Economics 11 (02): 159- 78. doi:10.1017/S1355770X05002755.

Mitchell, et Tanner. 2006. «Adapting to Climate Change: Challenges and opportunities for the development community », IDS and Tearfund édition.

Nelson, Richard R., et Edmund S. Phelps. 1966. «Investment in Humans, Technological Diffusion, and Economic Growth ». The American Economic Review 56 (1/2): 69- 75.

Nhemachena, Charles, Rashid M. Hassan, et Pradeep Kurukulasuriya. 2010. «Measuring the Economic Impact of Climate Change on African Agricultural Production Systems ». Climate Change Economics 1 (1): $35-55$.

Ophuls, William, et A. Stephen Boyan. 1992. Ecology and the Politics of Scarcity Revisited: The Unraveling of the American Dream. W.H. Freeman.

Ringler, Claudia, Ximing Cai, Jinxia Wang, Akhter Ahmed, Yunpeng Xue, Zongxue Xu, Ethan Yang, et al. 2010. « Yellow River basin: living with scarcity ». Water International 35 (5): 681- 701. doi:10.1080/02508060.2010.509857.

Ringler, C., T. Zhu, X. Cai, J. Koo, et D. Wang. 2010. « Climate Change Impacts on Food Security in Sub-Saharan Africa ».

Sen, Amartya. 1983a. Poverty and Famines: An Essay on Entitlement and Deprivation. Oxford University Press. 1983b. Poverty and Famines: An Essay on Entitlement and Deprivation. Oxford University Press, USA. . 2000. «Democracy as a Universal Value. » American Educator 24 (2): 16-22,50- 52.

Smith, Lisa C., et Lawrence James Haddad. 2000. « Explaining child malnutrition in developing countries: a cross-country analysis ». Research reports 111. International Food Policy Research Institute (IFPRI). http://ideas.repec.org/p/fpr/resrep/111.html.

UNDP. 1994. «Human Development Report ». New York Oxford University Press: United Nations Development Programme.

Wiesmann, Doris. 2006. 2006 Global Hunger Index: A Basis for Cross-Country Comparisons. Intl Food Policy Res Inst. 


\section{Appendix}

Appendix 1: Variables definition and sources

\begin{tabular}{|l|l|l|}
\hline Variables & Definition & Source \\
\hline Food supply & $\begin{array}{l}\text { Food supply refers to the total amount of the commodity } \\
\text { available as human food during the reference period. Food } \\
\text { supply is the total of food production + food import- food } \\
\text { exports food stocks variation. }\end{array}$ & FAO (2011) \\
\hline Rainfall volatility & $\begin{array}{l}\text { It is the absolute deviation of the yearly average rainfall } \\
\text { from its own trend (long-term mean of rainfall 1950-2008). }\end{array}$ & $\begin{array}{l}\text { Calculated by the } \\
\text { authors using the } \\
\text { data from CERDI } \\
\text { (2011) }\end{array}$ \\
\hline Rainfall & Yearly average of rainfall. & CERDI (2011) \\
\hline Food price vulnerability & $\begin{array}{l}\text { The FPV index is a weighted average of the following } \\
\text { variables: ratio of food imports to total household } \\
\text { consumption, ratio of total food imports to total imports of } \\
\text { goods and services, and the inverse of the level of GDP } \\
\text { per capita. }\end{array}$ & $\begin{array}{l}\text { Authors from Wovelopment Indicators } \\
\text { (2011) }\end{array}$ \\
\hline Income per capita & Gross Domestic Product per capita & WDI (2011) \\
\hline Population growth & Annual population growth rate & WDI (2011) \\
\hline Democratic institutions & $\begin{array}{l}\text { The Polity Score captures the regime authority spectrum on } \\
\text { a 21-point scale ranging from -10 (hereditary monarchy) to } \\
+10 \text { (consolidated democracy). }\end{array}$ & Polity IV (2010) \\
\hline Arable land & Arable area as percentage of total land area & WDI (2011) \\
\hline Cereal production land & $\begin{array}{l}\text { Cereal4 production area refers to harvested area or land } \\
\text { under cereal production }\end{array}$ & WDI (2011) \\
\hline Aid & $\begin{array}{l}\text { Net aggregate official development assistance transfers } \\
\text { (2011 US\$ millions) per capita }\end{array}$ & WDI (2012) \\
\hline $\begin{array}{l}\text { Real effective } \\
\text { exchange rate (REER) }\end{array}$ & $\begin{array}{l}\text { REE is the nominal effective exchange rate (a measure of } \\
\text { several foreign currencies) divided by a price deflator or } \\
\text { index of costs. }\end{array}$ & IFS (2011) \\
\hline
\end{tabular}

Source: Compilation created by author.

Appendix 2: Descriptive statistics of variables

\begin{tabular}{lllll}
\hline \hline Variable & Mean & Std. Dev. & Min & Max \\
\hline Food supply & 389.04 & 153.74 & 18.63 & 1318.99 \\
Rainfall variability & 10.37 & 10.35 & 0.001 & 118.69 \\
Rainfall & 1200.57 & 812.04 & 16.81 & 3882.82 \\
Shock price vulnerability & 46.15 & 64.45 & 0.84 & 381.48 \\
Aid per capita & 192.37 & 663.26 & -113.21 & 11258.35 \\
Per capita GDP & 6396.13 & 10374.16 & 84.28 & 95885.27 \\
Population growth & 1.88 & 1.54 & -4.64 & 16.24 \\
Democratic institutions & -0.52 & 5.64 & -10 & 10 \\
Land under cereal production & $2.2210^{7}$ & $7.1010^{7}$ & 0 & $6.9510^{8}$ \\
Arable land & 13.30 & 12.94 & 0 & 71.65 \\
Real effective exchange rate & 460.20 & 4391.8 & 40.85 & 97285.19 \\
\hline \hline
\end{tabular}

Source: Author's calculations.

3 To calculate this index, we use the principal component analysis (PCA) applied to three variables.

4 Cereals include wheat, rice, maize, barley, oats, rye, millet, sorghum, buckwheat, and mixed grains. 
Appendix 3: List of countries

\begin{tabular}{|c|c|c|}
\hline Albania & Honduras & Nicaragua \\
\hline Argentina & Croatia & Nepal \\
\hline Azerbaijan & Haiti & Pakistan \\
\hline Burundi & Indonesia & Panama \\
\hline Burkina Faso & India & Peru \\
\hline Bangladesh & Iran & Philippine \\
\hline Bulgaria & Jamaica & Paraguay \\
\hline Bolivia & Kenya & Rwanda \\
\hline Brazil & Kuwait & Sudan \\
\hline Botswana & Liberia & Senegal \\
\hline Chile & Libya & El Salvador \\
\hline China & Sri Lanka & Syria \\
\hline Cote d'Ivoire & Lithuania & Togo \\
\hline Cameroon & Morocco & Thailand \\
\hline Colombia & Moldavia & Trinidad and Tobago \\
\hline Costa Rica & Madagascar & Tanzania \\
\hline Algeria & Mexica & Uganda \\
\hline Ecuador & Mali & Ukraine \\
\hline Egypt & Mongolia & Uruguay \\
\hline Ethiopia & Mozambique & Venezuela \\
\hline Fiji & Mauritania & South Africa \\
\hline Gabon & Malaysia & Zambia \\
\hline Ghana & Niger & Zimbabwe \\
\hline Guatemala & Nigeria & \\
\hline
\end{tabular}

Source: WDI (2011). 